\title{
PENGEMBANGAN PERANGKAT PEMBELAJARAN IPA TOPIK ENERGI DALAM SISTEM KEHIDUPAN DI MADRASAH TSANAWIYAH
}

\author{
Nurul Hidayati \\ MTs Negeri Barabai \\ Email:nhidayati32@yahoo.com
}

\begin{abstract}
ABSTRAK
Penelitian pengembangan ini bertujuan untuk mengembangkan perangkat pembelajaran topik energi dalam sistem kehidupan model inkuiri terbimbing di MTs yang valid, praktis dan efektif. Jenis penelitian ini adalah penelitian pengembangan yang menggunakan model Tessmer. Model Tessmer dilakukan dengan tahapan yaitu tahapan self evaluation, expert reviews, one-one, small group, dan field test. Subjek uji penelitian adalah subjek uji coba pakar yang berasal dari tim dosen yang sekurang-kurangnya mempunyai kualifikasi magister pendidikan. Subjek uji coba perorangan dilakukan dengan 6 siswa yang mempunyai kemampuan akademik yang berbeda, subjek uji coba kelompok kecil dilakukan pada siswa kelas VIIB dengan jumlah siswa 18 orang, subjek uji coba lapangan dilakukan pada siswa kelas VIIA yang berjumlah 40 orang. Seluruh data diperoleh dari instrumen pengumpulan data dan dianalisis secara deskriptif. Hasil penelitian menunjukkan perangkat pembelajaran tergolong valid, praktis dan efektif. Dikatakan valid berdasarkan hasil validasi menunjukkan silabus, RPP, bahan ajar, LKS, media pembelajaran, dan instrumen penilaian termasuk kriteria sangat valid. Praktis karena hasil perorangan menunjukkan siswa mampu memahami bahan ajar dan LKS yang diberikan. Dikatakan efektif karena (1) hasil belajar kognitif produk dan kognitif proses telah tuntas, (2) kinerja siswa rata-rata kategori sangat baik, (3) perilaku berkarakter siswa (disiplin dan tanggung jawab) kategori sangat baik, (4) keterampilan sosial siswa (bekerja sama dan menyumbang ide) kategori sangat baik, (5) keterampilan berpikir kritis siswa pada saat melakukan kegiatan percobaan kategori sangat baik.
\end{abstract}

Kata kunci: penelitian pengembangan, high quality intervention, model Tessmer.

\begin{abstract}
This research is purposed to develop teaching and learning aids on energy in living systems topics through guided inquiry model in Junior Islamic High School (MTs) in valid, practical, and effective manners. The research is using Tessmer model research development conducted in a series of stages, namely: self evaluation, expert reviews, one-one, small group and field test.The research trial subjects are expert trial subjects consist of lecturer having master of education qualification, while the individual trial subjects involved 6 students. The small group trial subjects involved Grade VII B consiting of 18 students. The field subject involved the Grade VII A consisting of 40 students. The whole data is collected using the data collecting instruments and is descriptively analyzed. The teaching and learning aids are classified as valid based on the result of validation by the expert that is showing the syllabus, lesson plans, teaching materials, worksheets, instructional media, and assessments instruments fulfill the valid criteria. The teaching and learning aids are classified as valid after making some revisions. Learning instrument is classified as practical based on the result of readability test (individual test) showed that the ability of students to understand the given teaching materials and worksheets. Learning instrument is classified as effective based on: (1) the result of cognitive learning product and cognitive
\end{abstract}


processes showed that the students have achieved learning mastery through pretest and posttest activities, (2) the psychomotor average students performance is categorized as very good, (3) the character behaviors of the students (discipline and responsibility) is categorized as very good, (4) the social skills of the students (cooperation and contribute ideas) is categorized as very good, (5) the students' critical thinking skills in conducting an experiment is categorized as very good.

Key words: Developing research, high quality intervention, the models of Tessmer.

\section{PENDAHULUAN}

Komponen - komponen proses pembelajaran seperti tujuan, bahan atau materi yang dipelajari, strategi pembelajaran, siswa dan guru sebagai subjek belajar, media pembelajaran dan penunjang proses pembelajaran dapat mempengaruhi hasil belajar (Sugandi, 2008). Komponen-komponen ini saling terkait. Bilamana satu komponen lemah maka akan menghambat pencapaian tujuan pembelajaran secara maksimal.

Kurikulum 2013 dirancang untuk memperkuat kompetensi siswa dan sisi pengetahuan, keterampilan dan sikap secara utuh. Proses pencapaiannya dilakukan melalui pembelajaran pada sejumlah mata pelajaran yang dirangkai, sebagai suatu kesatuan yang saling mendukung pencapaian kompetensi tersebut. Bila pada jenjang SD/MI, semua mata pelajaran digabung menjadi satu dan disajikan dalam bentuk tema-tema, maka pada jenjang SMP/MTs pembelajaran sudah mulai dipisah-pisah menjadi mata pelajaran (Nuh, 2013). Uno, dkk, (2011) menjelaskan guru dituntut lebih kreatif dalam mengajar, dan kreatif mengembangkan kemampuan mengajar pedagogik dalam proses pembelajaran. Salah satu usaha yang dapat dilakukan adalah memberikan kesempatan kepada guru untuk belajar.

Nuh (2013) mengutip hasil riset Program for International Student
Assessment (PISA), studi yang memfokuskan pada literasi bacaan, matematika, dan IPA menunjukkan peringkat Indonesia hanya menduduki 10 besar terbawah dari 65 negara. Hasil Riset Trends International Mathematics and Science Study (TIMSS) menunjukkan siswa Indonesia berada pada rangking amat rendah dalam kemampuan (1) memahami informasi yang komplek, (2) teori,analisis dan pemecahan masalah, (3)pemakaian alat, prosedur dan pemecahan masalah dan (4) melakukan investigasi. Hasil ini menunjukkan perlu adanya perubahan orientasi kurikulum, dengan tidak membebani peserta didik dengan konten namun pada aspek kemampuan esensial yang diperlukan semua warga negara untuk berperan serta dalam membangun negaranya pada abad 21 .

Kualitas sumber daya manusia dapat dilihat dari kemampuan yang dimiliki, baik terkait dengan pengetahuan maupun keterampilannya dan sikapnya (Ali, 2009). Ketrampilan berpikir kritis belum menjadi hal mutlak yang harus ada sebagai hasil belajar siswa. Jika hal ini dibiarkan maka siswa terbiasa menghapal fakta tanpa memahami artinya.

Melihat kenyataan di atas adalah suatu tantangan bagi guru untuk dapat membelajarkan materi pelajaran tidak hanya memahami konsep saja tapi harus juga disertai dengan pemahaman proses yang berdasarkan pada keterampilan 
berpikir kepada peserta didik. Untuk mencapai keinginan tersebut maka pembelajaran harus direncanakan, dinilai dan dievaluasi. Hal ini sesuai dengan pendapat dari Syatra (2013) yang mengatakan bahwa seorang guru dituntut untuk merencanakan strategi pembelajaran yang variatif dengan prinsip pembelajaran dan memberdayakan anak didik, bukan mengajar anak didik. Anak didik belajar dengan mengalami sendiri, mengontruksi pengetahuan, kemudian memberikan makna pada pengetahuan itu.

Salah satu model pembelajaran yang memberikan kesempatan kepada siswa untuk memperbaiki proses belajar adalah model inkuri. Model inkuiri memberikan kesempatan kepada guru untuk menggali keterampilan berpikir kritis (critical thinking) dan berpikir kreatif (creative thinking). Kedua keterampilan berpikir ini merupakan keterampilan berpikir tingkat tinggi (high order thinking skill) yang selalu ditekankan dalam pembelajaran sains modern.

Menurut Lohner dkk, (2005), pembelajaran inkuiri menawarkan pengalaman otentik dengan melibatkan siswa dalam proses konstruksi pengetahuan. Model inkuiri sering disebut sebagai 'Penemuan terbimbing'. Guru memandu inkuiri siswa 'sampai siswa menemukan' konsep sains yang ditentukan oleh guru (Mc Bride, dkk., 2012).

Keberhasilan pendidikan tergantung apa yang diajarkan guru (Shoimin, 2014). Guru seharusnya memanfaatkan perkembangan ilmu dan teknologi dalam pembelajaran dengan melakukan inovasi dalam pembelajaran. Guru yang memiliki kemauan dalam menggali metode dalam pembelajaran akan menciptakan modelmodel baru sehingga murid tidak mengalami kebosanan dalam belajar.
Kunandar (2010), menyatakan pembelajaran inkuiri adalah kegiatan pembelajaran di mana siswa didorong untuk belajar melalui keterlibatan aktif mereka sendiri dengan konsep-konsep dan prinsip-prinsip. Gulo (2002) menyatakan strategi inkuiri berarti suatu rangkaian kegiatan belajar yang melibatkan secara maksimal seluruh kemampuan siswauntuk mencari dan menyelidiki secara sistematis, kritis, logis, analitis, sehingga siswa dapat merumuskan sendiri penemuannya dengan penuh percaya diri. Model pembelajaran inkuiri dimaksudkan untuk membantu pelajar secara ilmiah, terampil mengumpulkan fakta, menyusun konsep, menyusun generalisasi secara mandiri.

Standar proses seperti tertuang di dalam Permendikbud No. 65 tahun 2013. Ini berkaitan dengan pelaksanaan pembelajaran pada satuan pendidikan, dan berlaku pada satuan pendidikan dasar dan menengah di seluruh wilayah hukum Negara Kesatuan Republik Indonesia. Pengembangan perangkat pembelajaran berdasarkan Permendikbud No. 65 Tahun 2013 akan berhubungan dengan pemanfaatan TIK. Hal ini untuk memenuhi tuntutan keterampilan siswa abad ke-21 yakni bagaimana berpikir kritis, mencari solusi, kreatif serta memiliki keterampilan informasi dan media diperlukan pembelajaran menggunakan TIK.

Penerapan model inkuiri telah melahirkan perbaikan pembelajaran. Meningkatkan aktivitas siswa, perbaikan hasil belajar, dan sikap ilmiah (Rohmawati, 2013; Hermawati, 2012; Setiawati, 2013). Model inkuiri juga dapat meningkatkan perbaikan karakter siswa (Asyhari, dkk., 2014; Sukamsyah, 2011).

Penitian ini bertujuan mengembangkan perangkat pembelajaran yang 
valid dan efektif topik Energi dalam Sistem Kehidupan menggunakan model inkuiri terbimbing untuk meningkatkan berpikir kritis siswa.

\section{METODE}

Penelitian pengembangan menggunakan model Tessmer (Tessmer, 1993). Seperti Gambar 1.

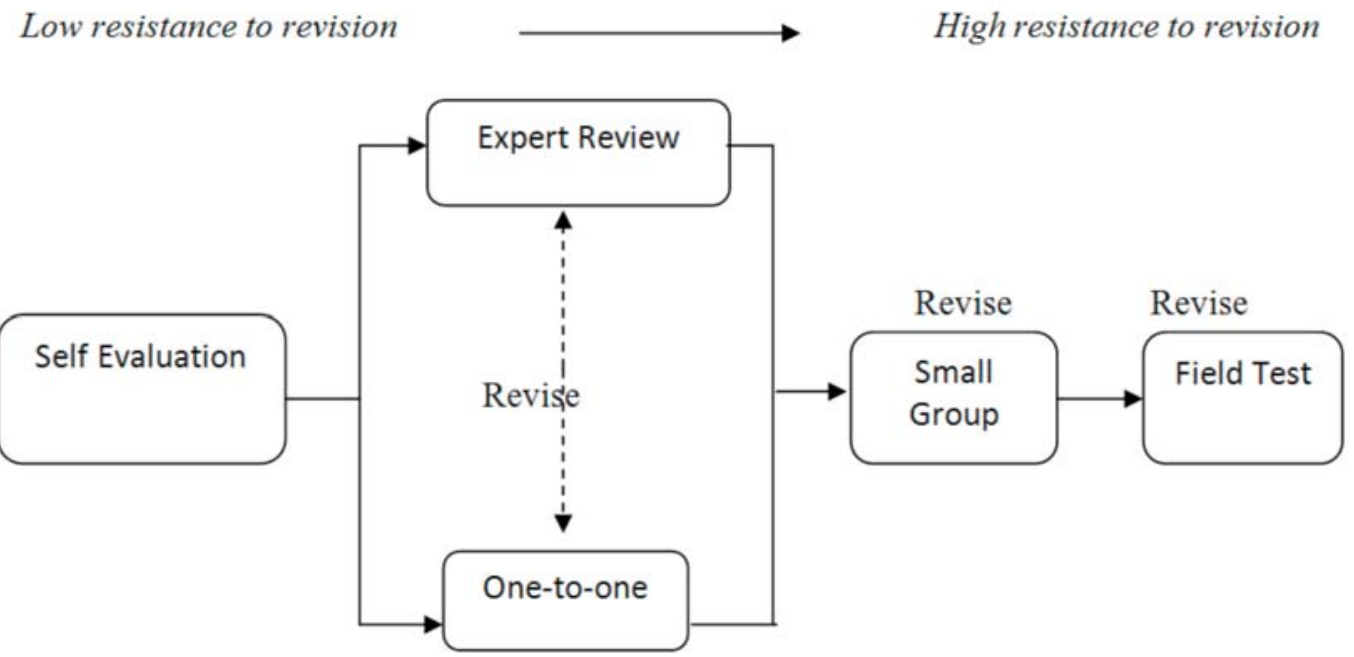

Gambar 1 Alur Desain Formative Evaluation (Tessmer, 1993)

Penelitian ini dilakukan tanggal 11-30 Mei 2015 di MTs Negeri Barabai. MTs Negeri Barabai beralamat di Jalan Abdul Muis Ridhani No. 80 Barabai Kabupaten Hulu Sungai Tengah. Subjek uji coba pakar berasal dari tim dosen ber kualifikasi magister pendidikan. Subjek uji coba perorangan 6 orang siswa yang mempunyai kemampuan akademik yang berbeda, subjek uji coba kelompok kecil siswa kelas VIIB berjumlah 18 orang, subjek uji coba lapangan siswa kelas VIIA berjumlah 40 orang. Penetapan subyek uji coba secara purposive, dan uji coba produk melalui empat tahapan tadi.

\section{1) Expert Review (Pendapat Ahli)}

Setelah dilakukan evaluasi diri, draf perangkat RPP diserahkan ke tim pakar untuk divalidasi. Maksudnya untuk mendapatkan masukan, saran, komentar. Dan dijadikan bahan untuk merevisi draf I sehingga dihasilkan draf II. Revisi dari tiga ahli digunakan sebagai bahan untuk diujicobakan pada uji perorangan.

\section{2) One-to one (Uji perorangan)}

Pada tahap ini peneliti menyampaikan maksud ujicoba LKS dan bahan ajar kepada peserta didik, bahwa uji coba ini bertujuan untuk melihat kemampuan mereka dalam memahami maksud bahasa dari LKS dan bahan ajar, dan ingin mengetahui apakah ada yang tidak dimengerti atau tidak jelas dari LKS dan bahan ajar, dan ini dilakukan terhadap masing-masing siswa. Kekurangankekurangan yang ada kemudian diperbaiki dan menghasilkan draf III yang kemudian akan diujicobakan pada uji kelompok kecil.

\section{3) Small group (uji kelompok kecil)}

Hasil dari uji kelompok kecil menghasilkan draf IV akan digunakan dalam menilai kepraktisan. Kepraktisan dilihat pada pelaksaanaan di kelas yaitu untuk mengamati kemudahan guru dalam pelaksanakan perangkat RPP menggunakan instrument penilaian. 
Kepraktisan juga diukur melalui respon siswa terhadap kegiatan belajar mengajar dan respon siswa terhadap pembelajaran menggunakan model inkuiri terbimbing. Bilamana perangkat pembelajaran dinyatakan praktis selanjutnya digunakan untuk uji lapangan.

\section{4) Field Test (uji lapangan)}

Uji lapangan untuk menetapkan keefektivan perangkat pembelajaran. Jenis data yang diperoleh untuk menetapkan keefektivan meliputi a) hasil belajar kognitif produk, b) hasil belajar kognitif proses c) hasil penilaian psikomotor, d) hasil penilaian perilaku berkarakter, e) hasil penilaian keterampilan social, f) hasil penilaian kemampuan berpikir kritis, dan f) hasil penilaian aktivitas siswa.
Instrumen yang digunakan dalam penelitian ini yaitu 1) Lembar evaluasi diri, menggunakan lembar instrumen evaluasi diri, 2) Lembar kajian ahli, menggunakan instrumen kajian ahli, 3) Lembar uji perorangan, menggunakan instrumen keterbacaan siswa, 4) Angket respon siswa terhadap pembelajaran dan komponen pembelajaran.

1. Data hasil validasi perangkat dianalisis secara deskriptif menggunakan rumus:

$$
V=\frac{T S e}{T S h} \times 100 \%
$$

Keterangan: $\mathrm{V}=$ Validitas; $\mathrm{TSe}=$ Total skor hasil validasi dari validator; $\mathrm{TSh}=$ Total skor maksimal yang diharapkan

Hasil validitas dicocokkan dengan kriteria validitas, menggunakan Tabel 1.

Tabel 1. Kriteria Perangkat Pembelajaran

\begin{tabular}{cl}
\hline \multicolumn{1}{c}{ Interval } & \multicolumn{1}{c}{ Keputusan/ } \\
\hline $85,00-100,00 \%$ & Sangat valid, atau dapat digunakan tanpa revisi \\
$70,01-<85,00 \%$ & Cukup valid, atau dapat digunakan namun perlu direvisi kecil \\
$50,01-<70,00 \%$ & Kurang valid, disarankan tidak dipergunakan karena perlu revisi \\
& besar \\
$01,00-<50,00 \%$ & Tidak valid, atau tidak boleh dipergunakan \\
\hline
\end{tabular}

Sumber : Adaptasi dari Akbar (2013)

2. Data hasil kepraktisan dilihat dari keterlaksanaan RPP dan respon siswa.

a) Keterlaksanaan RPP dianalisis secara deskriptif dan diukur menggunakan rumus:

$$
\boldsymbol{X}=\frac{\sum X}{\boldsymbol{n}}
$$

Keterangan: $\mathrm{X}=$ Rata-rata kepraktisan, $\Sigma \mathrm{X}=$ Jumlah nilai kegiatan, $\mathrm{n}=$ Banyaknya kegiatan

b) Respon siswa terhadap pembelajaran dianalisis secara deskriptif menggunakan skor 0, 1, 2, 3, 4. Skor 4 (sangat setuju), 3 (setuju), 2 (raguragu), 1 (tidak setuju), dan 0 (sangat tidak setuju). Selanjutnya dihitung menggunakan rumus:

$$
X=\frac{\sum X}{n} x 100
$$

Keterangan: $X=$ Rata-rata respon siswa, $\Sigma \mathrm{X}=$ Jumlah nilai kegiatan, $\mathrm{n}=$ Jumlah skor maksimal

3. Data hasil keefektivan diperoleh dari data secara kuantitatif meliputi :

a) Data hasil belajar kognitif produk dianalisis secara deskiptif menggunakan rumus:

$$
P=\frac{N}{100} \times 4
$$

Keterangan: $\mathrm{P}=$ Nilai Pretes/Postes, $\mathrm{N}=$ Nilai Siswa 
b) Data hasil belajar kognitif proses dianalisis secara deskriptif dan diukur dengan menggunakan rumus :

$$
P=\frac{N}{100} \times 4
$$

Keterangan: $\mathrm{P}=$ Nilai Pretes/Postes,

$$
\mathrm{N}=\text { Nilai Siswa }
$$

c) Data hasil penilaian psikomotor dianalisis secara deskriptif menggunakan rumus :

Skor keterampilan psikomotor siswa $($ oleh siswa $)=$

$$
\frac{\text { skor siswa }}{\text { total skor }} \times 100=\frac{\cdots}{100} \times 100=\cdots
$$

Skor keterampilan psikomotor siswa (oleh guru $)=$

$$
\frac{\text { skor siswa }}{\text { total skor }} \times 100=\frac{\cdots}{100} \times 100=\cdots
$$

d) Data hasil penilaian perilaku berkarakter dan keterampilan sosial, dan aktivitas siswa dianalisis secara deskriptif menggunakan rumus:

$$
\boldsymbol{X}=\frac{\sum X}{\boldsymbol{n}}
$$

Keterangan: $X=$ aktivitas rata-rata, $\Sigma \mathrm{X}=$ jumlah aktivitas, $\mathrm{n}=$ banyaknya aktivitas e) Data hasil penilaian keterampilan berpikir kritis dianalisis secara deskriptif menggunakan rumus:

Skor keterampilan berpikir kritis siswa (oleh siswa $)=$

$$
\frac{\text { skor siswa }}{\text { total skor }} \times 100=\frac{\cdots}{100} \times 100=\cdots
$$

Skor keterampilan berpikir kritis siswa (oleh guru $)=$ $\frac{\text { skor siswa }}{\text { total skor }} \times 100=\frac{\cdots}{100} \times 100=\cdots$

\section{HASIL DAN PEMBAHASAN}

Silabus yang dihasilkan kategori sangat valid. Rencana Pelaksanaan Pembelajaran termasuk kategori sangat valid. Bahan ajar yang dikembangkan termasuk kategori sangat valid. Lembar Kerja Siswa hasil pengembangan juga kategori sangat valid. Media Pembelajaran hasil pengembangan termasuk kategori sangat valid. Lembar Penilaian hasil pengembangan juga kategori sangat valid.

Perangkat pembelajaran mendapat masukan dari ahli disajikan pada Tabel 2.

Tabel 2. Masukan/saran dari para ahli terhadap perangkat pembelajaran

\begin{tabular}{lll}
\hline No. & \multicolumn{1}{c}{ Masukan/Saran dari Para ahli } & \multicolumn{1}{c}{ Sesudah revisi } \\
\hline 1 & $\begin{array}{l}\text { Ahli/Validator I } \\
\text { Buat perangkat sesuai dengan ketentuan yang } \\
\text { berlaku }\end{array}$ & $\begin{array}{l}\text { Membuat perangkat sesuai dengan } \\
\text { ketentuan yang berlaku }\end{array}$ \\
2 & $\begin{array}{l}\text { Ahli/Validator II } \\
\text { a. Buat daftar pustaka pada silabus }\end{array}$ & $\begin{array}{l}\text { Sudah dicantumkan dafta pustaka } \\
\text { Sudah diperbaiki }\end{array}$ \\
& $\begin{array}{l}\text { b. Bentuk instrument dengan contoh instrument } \\
\text { pada silabus letaknya diperbaiki }\end{array}$ & \\
c. Lengkapi identitas sekolah & Sudah dilengkapi \\
d. Perbaiki tata cara penulisan pada RPP & Sudah diperbaiki \\
e. Konsisten penggunaan kata siswa atau peserta & Konsisten penggunaan kata siswa \\
f. Kidik & Konsisten penggunaan LKS
\end{tabular}




\begin{tabular}{|c|c|c|}
\hline No. & Masukan/Saran dari Para ahli & Sesudah revisi \\
\hline & $\begin{array}{l}\text { g. Lay out bahan ajar sebaiknya dibuat lebih } \\
\text { menarik }\end{array}$ & Sudah diperbaiki \\
\hline & $\begin{array}{l}\text { h. Media dalam PPT belum memnuhi semua tujuan } \\
\text { pembelajaran dan belum ada gambar }\end{array}$ & $\begin{array}{l}\text { Sudah diperbaiki dan } \\
\text { mencantumkan gambar }\end{array}$ \\
\hline \multirow[t]{9}{*}{3} & Ahli/Validator III & \\
\hline & $\begin{array}{l}\text { a. Pada silabus belum termuat secara eskplisist } \\
\text { pencantuman kegiatan pembelajaran }\end{array}$ & $\begin{array}{l}\text { Sudah dicantumkan kegiatan } \\
\text { pembelajaran }\end{array}$ \\
\hline & $\begin{array}{l}\text { b. Cek lagi degree pada rumusan tujuan } \\
\text { pembelajaran }\end{array}$ & Sudah diperbaiki \\
\hline & $\begin{array}{l}\text { c. Belum mencantumkan alat dan bahan pada } \\
\text { pembelajaran }\end{array}$ & Sudah dicantumkan alat dan bahan \\
\hline & d. Buat indikator pada RPP & Sudah dibuat indikator \\
\hline & $\begin{array}{l}\text { e. Pada bahan ajar tambahkan rangkuman, daftar } \\
\text { pustaka, hurufnya diperbesar sesuaikan dengan } \\
\text { anak MTsN }\end{array}$ & Sudah diperbaiki \\
\hline & $\begin{array}{l}\text { f. Pada media pembelajaran tambahkan gambar, } \\
\text { tambahkan langkah-langkah inkuiri dan bahan } \\
\text { ajar dibuat semenarik mungkin agar siswa } \\
\text { tertarik untuk memperhatikannya }\end{array}$ & Sudah ditambahkan gambar \\
\hline & $\begin{array}{l}\text { g. Pada LKS tambahkan sumber dan cek lagi } \\
\text { penulisannya }\end{array}$ & Sudah diperbaiki \\
\hline & h. Pada LP 1 tambahkan daftar pustaka & Sudah dicantumkan daftar pustaka \\
\hline
\end{tabular}

Pendapat siswa tentang LKS mempunyai nilai 93,7 (sangat baik), bahan ajar mempunyai nilai 93,7 (baik). Hasil pengamatan keterlaksaan RPP dilakukan oleh Norhasanah, M. Pd sedangkan pengamat untuk siswa dilakukan oleh Indah Rosmalina, M. Pd dan Astuti Pigiani, S. Pd. Nilainya adalah 87,5 (sangat baik). Sebagian besar siswa memberikan respon senang terhadap pembelajaran. Indikator ini meliputi a) materi/isi pelajaran, b) suasana pembelajaran, c) cara guru mengajar, d) kegiatan praktikum, dan e) bekerja dalam kelompok.

Hasil belajar kognitif produk secara klasikal ketuntasan melampaui KKM (92,5\%) Hasil belajar kognitif proses secara klasikal ketuntasan juga melampaui KKM (92,5\%). Penilaian psikomotor siswa nilai rata-rata 97,1 (sangat baik). Penilaian Perilaku Berkarakter rata-rata 97,5 (sangat baik). Pengamatan keterampilan sosial (bekerja sama dan menyumbang ide) rataratanya 97,5 (sangat baik).

Pengamatan keterampilan berpikir kritis (melaksanakan langkah-langkah inkuiri) rata-rata baik. Hasil pengamatan aktivitas siswa pada setiap pertemuan nilainya 92,5 (sangat baik). Indikator yang diamati adalah a) Siswa memperhatikan penjelasan guru, b) Siswa mengajukan pertanyaan, c) Siswa duduk berkelompok, d) Siswa mengerjakan LKS, e) Siswa melakukan pengamatan/percobaan, f) Siswa membuat kesimpulan, dan g) Siswa mempresentasikan hasil kerja kelompok.

Penelitian telah menghasilkan perangkat pembelajaran topik energi dalam sistem kehidupan model inkuiri terbimbing yang valid, praktis, dan efektif. Pembahasan di sini menekankan pada keefektivan sebuah prototipe perangkat pembelajaran, sedangkan pembahasan kepraktisan hanya sekilas saja. 
Uji perorangan sebagai sarana mengukur kepraktisan didapat tanggapan positif terhadap isi LKS dan bahan ajar walaupun memang ada beberapa orang yang masih belum paham tentang pelaksanaannya karena di dalam LKS memuat langkah-langkah inkuiri yang bagi mereka itu adalah hal yang masih baru, selain itu ada 2 orang siswa yang menilai bahan ajar yang diberikan kurang mereka pahami khususnya pada bagain bahasa, dan gambar yang kurang jelas. Sebagian besar merespon positif dan tertarik terhadap materi pembelajaran, suasana pembelajaran, cara guru mengajar, kegiatan praktikum dan bekerja sama dalam kelompok. Hal ini sesuai dengan teori belajar kontruktivisme yang mengatakan bahwa guru tidak hanya sekedar memberikan pengetahuan kepada siswa. Siswa harus membangun sendiri pengetahuan dibenaknya.

Respon siswa rata-rata cukup baik atau setuju dengan penggunaan model inkuiri dalam pembelajaran, walaupun ada yang merespon ragu-ragu terhadap pernyataan yang diberikan. Respon yang beragam tersebut disebabkan karena mereka masih beradaptasi dengan model inkuiri yang jarang sekali digunakan pada saat proses pembelajaran, alasannya guru harus mempersiapkan peralatan dan bahan, bahan-bahan praktikum yang sulit didapat, apalagi jumlah siswa yang terlalu banyak (rata-rata satu kelas diisi oleh 40 siswa). Menurut Shoimin (2014) hasilnya kurang efektif jika pembelajaran ini diterapkan pada situasi kelas yang kurang, mendukung.

Observasi aktivitas guru pada pertemuan siswa masih belum terampil untuk membuat rumusan masalah dan guru terlalu sering membimbing siswa untuk melakukan setiap langkah inkuiri. Ketika membuat rumusan masalah dan hipotesis mereka masih kebingungan. Guru masih belum maksimal dalam menanamkan kebiasaan positif siswa dan guru masih lebih aktif daripada siswa, hal ini karena guru masih terbiasa dengan model lama yang fokus sentral kegiatan pembelajaran pada guru dan belum terbiasa untuk memberikan kebebasan menyampaikan pendapat dari siswa, seharusnya siswa sendiri yang harus menemukan informasi konsep materi sehingga pada akhirnya konsep tersebut lebih bermakna. Kegiatan pembelajaran berikutnya sudah mulai terbiasa untuk membuat rumusan masalah dan hipotesis walaupun masih ada kelompok yang masih salah dalam membuatnya.

Uji coba lapangan didapat guru dinilai kurang maksimal dalam mengecek penguasaan keterampilan proses yang dilatihkan selama proses pembelajaran. Sehingga dari sisi pengajar perlu dikembangkan ketelitian dan keluwesan dalam mengamati siswa pada saat melakukan percobaan sehingga manajemen waktu yang sudah direncanakan dapat berjalan dengan baik.

Ketuntasan hasil belajar telah tercapai, menurut Piaget dalam Cahyo (2013) bahwa tahap perkembangan kognitif anak memberi pamahanan kepada kita bahwa tahap tertentu cara maupun kemampuan anak mengkontruksi ilmu berbeda-beda berdasarkan kematangan intelektual anak. Interaksi dengan lingkungan turut mempengaruhi kematangan intelektual anak, hal inilah yang menyebabkan nilai yang didapat juga berbeda-beda.

Hasil belajar kognitif proses menggunakan model inkuiri terbimbing ternyata siswa yang nilaia nya tuntas ada 37 orang $(92,5 \%)$ dan masih ada tiga orang siswa yang belum tuntas $(2,5 \%)$. 
Penggunaan model inkuri dalam proses pembelajaran dapat membantu siswa menemukan sendiri jawaban dari suatu permasalahan yang ingin dipecahkannya. Hasil penelitian ini sejalan dengan penelitianpenelitian yang sudah dilaporkan sebelumnya (Romadhoni, 2011; Sukamsyah, 2011; Hermawati, 2012; Rosmalina, 2012; Rohmawati, 2013; Asyhari, dkk 2014) bahwa ada perbedaan hasil yang didapat setelah menggunakan pembelajaran model inkuiri yaitu mengalami peningkatan nilai yang didapat oleh siswa.

Kemampuan psikomotor siswa nilainya rata-rata sangat baik, hal ini karena hampir semua kelompok dapat menggunakan perlatan tersebut sesuai dengan rincian tugas kinerja yang telah disusun oleh guru. Hal ini sejalan dengan pendapat Sanjaya (2006), di mana dalam pembelajaran langsung merupakan pengalaman yang diperoleh siswa sebagai hasil dari aktivitas sendiri. Siswa mengalami, merasakan sendiri segala sesuatu yang berhubungan dengan pencapaian tujuan. Siswa berhubungan langsung dengan objek yang hendak mereka pelajari tanpa menggunakan perantara. Karena Pengalaman langsung inilah maka ada kecenderungan hasil yang diperoleh siswa menjadi konkret sehingga akan memiliki ketepatan yang tinggi.

Keterampilan perilaku berkarakter disetiap pertemuan dan peningkatannya ke arah yang sangat baik. Hal tersebut sejalan dengan pendapat dari Sanjaya (2006), di mana didalam proses pembelajaran di sekolah, baik secara disadari maupun tidak, guru dapat menanamkan sikap tertentu kepada siswa melalui proses pembiasaan, dan menanamkan sikap yang positif bukanlah pekerjaan yang mudah.

Keterampilan perilaku sosial siswa yang diamati adalah bekerja sama dan menyumbang ide dan nilai yang diperoleh rata-rata baik. Selama ini siswa terbiasa sebagi objek dalam pembelajaran sehingga mereka tidak terbiasa untuk mengeluarkan pendapat apalagi untuk menyumbangkan ide. Inilah yang melatarbelakangi sehingga nilainya lebih rendah. Menurut Wadsworth (1989) dalam Sanjaya (2006), bahwa pengetahuan sosial tidak dapat dibentuk dari suatu tindakan seseorang terhadap suatu objek, tetapi dibentuk dari interaksi seseorang dengan orang lain. Ketika anak melakukan interaksi dengan temannya, maka kesempatan untuk membangun pengetahuan sosial dapat berkembang.

Keterampilan berpikir kritis siswa sudah mulai terbiasa untuk melaksanakan langkah-langkah inkuiri Hal ini sesuai dengan teori dari Piaget yang mengatakan bahwa masalah dapat dipecahkan melalui penggunaan eksperimentasi sistematik. Pengamatan aktivitas siswa hasilnya ratarata baik, walaupun ada beberapa anggota dalam kelompok yang pada pertemuan pertama masih melakukan aktivitas yang tidak relevan dengan proses pembelajaran, tapi guru berusaha untuk mengingatkan siswa untuk selalu aktif dan bekerja sama dalam kelompok, pada akhirnya kegiatan yang tidak relevan tersebut bisa berkurang di setiap pertemuan.

\section{SIMPULAN}

Berdasarkan hasil penelitian maka dipeoleh beberapa simpulan sebagai berikut: (1) Perangkat pembelajaran topik Energi dalam Sistem Kehidupan menggunakan model inkuiri terbimbing hasil pengembangan sudah sangat valid setelah dilakukan beberapa kali revisi. (2) Kepraktisan perangkat pembelajaran dihasilkan dari respon siswa dan keterlaksanaan RPP. Respon siswa menilai bahwa LKS dan bahan ajar yang dibuat mudah untuk dipahami, sedangkan 
keterlaksanaan RPP menunjukkan kategori sangat baik. Perangkat pembelajaran efektif digunakan dalam pembelajaran berdasarkan hasil uji lapangan yang meliputi hasil belajar kognitif produk dan kognitif proses menunjukkan siswa telah mencapai ketuntasan belajar melalui kegiatan pretes dan postes, kinerja psikomotor siswa rata-rata kategori sangat baik, perilaku berkarakter siswa (disiplin dan tanggung jawab) kategori sangat baik, keterampilan sosial siswa (bekerja sama dan menyumbang ide) kategori sangat baik, dan keterampilan berpikir kritis siswa pada saat melakukan kegiatan percobaan kategori sangat baik.

\section{DAFTAR PUSTAKA}

Ali, M. 2009. Pendidikan untuk pembangunan Nasional. Jakarta: PT. Imperial Bhakti Utama.

Asyhari, A.T, dan Sunarto, W.T, dan Sarwanto,S,2014."Pengembangan Perangkat Pembelajaran Fisika SMA Berbasis Inkuiri Terbimbing Terintegrasi Pendidikan Berkarakter". 3 (01).

Cahyo, A.N.2013. Panduan Aplikasi Teori-teori Belajar Mengajar (Teraktual dan Terpopuler). Jogjakarta: PN. Diva Press.

Gulo, W. 2002. Strategi Belajar Mengajar. Jakarta: Grasindo.

Hermawati, N.W.M. 2012. Artikel Pengaruh Model Pembelajaran Inquri Terhadap Penguasaan Konsep Biologi da Sikap Ilmiah Siswa SMA Ditinjau dari Minat Belajar Siswa.

Kementrian Pendidikan dan Kebudayaan Republik Indonesia. 2013. Peraturan Mentri Pendidikan dan Kebudayaan Republik Indonesia No 65 Tahun 2013
Tentang Standar Proses untuk Satuan Pendidikan Dasar dan Menengah. Jakarta: Depdiknas.

Kunandar. 2010. Guru professional Implementasi Kurikulum Tingkat Satuan Pendidikan KTsP dan Sukses dalam Sertifikasi Guru. Jakarta: Rajawali Press.

Lohner, S; Van Joolingen, R. Wouter; Savelsbergh, R. Elwin; Wolters, and Bernadette. 2005. Students Reasoning During Modeling in an Inquiry Learning Environment. Computers in Human Behavior 21 (2005).

McBride; W. John; Bhatti, I. Muhammad; Hannan, A. Mohammad; and F. Martin. 2012. Using an inquiry approach to teach science to secondary school science teachers. Procedia - Social and Behavioral Sciences 46 (2012) 2327 - 2333.

Nuh, M. 2013. Materi Pelatihan Guru (Implementasi Kurikulum 2013 SMP/MTs Ilmu Pengetahuan Alam). Kementerian Pendidikan dan Kebudayaan.

Rohmawati,A.N.2013. Penerapan Pembelajaran IPA Terpadu dengan Model Pembelajaran Inquri pada Tema Mata di SMPN 1 Maduran Lamongan (Jurnal Online Universitas Negeri Surabaya, http://ejournal. unesa.ac.id (diakses 13 feb 2015)

Rosmalina, I.2012. Pengembangan Perangkat Pembelajaran Inquiri pada Konsep Ekosistem Terhadap Hasil Belajar dan Keterampilan Berpikir Tingkat Tinggi Siswa MTs Darul Istiqamah Putri Barabai. Banjarmasin Unlam.

Sanjaya, Wina. 2006. Stategi Pembelajaran Berorientasi Standar Proses Pendidikan. Jakarta: Kencana Prenadamedia Group. 
Setiawati, R. 2013. "Pengembangan Modul Berbasis Inkuiri Terbimbing untuk Mengoptimalkan Sikap Ilmiah Peserta Didik pada Pokok Bahasan Listrik Dinamis di SMAN 8 Purworejo kelas $X$ Tahun Pelajaran 2012/2013”. 3(1).

Shoimin, A. 2014. 68 Model Pembelajarn Inovatif dalam Kurikulum 2013. Yogyakarta: Ar-Ruz Media,

Sugandi, A. 2008. Teori Pembelajaran. Semarang: Unnes Press.

Sukamsyah, S. 2011. "Upaya Peningkatan Hasil Belajar dengan Penerapan Metode Inkuiri Terbimbing Tipe A pada Konsep Kalor Kelas VII SMPN 5 Seluma”. 9 (1): ISSN 1412-3617

Syatra, N.Y. 2013. Desain Relasi Efektif Guru dan Murid. Jogjakarta: Buku Biru.

Tessmer, M. 1993. Planning and conducting formative evaluations: Improving the quality of education and training. London: Kogan.

Uno, H.B dan N. Mohammad,. 2011. Belajar dengan Pendekatan PAILKEM. Jakarta: PT. Bumi Aksara, 